\title{
MENINGKATKAN KEMAMPUAN KOMUNIKASI MATEMATIS SISWA MELALUI MODEL PEMBELAJARAN KOOPERATIF TIPE STAD DENGAN PENDEKATAN RECIPROCAL TEACHING
}

\author{
Fitry Wahyuni \\ Prodi Pendidikan Matematika STKIP Pelita Bangsa Binjai \\ wahyunifitry17@gmail.com
}

\begin{abstract}
This study aims to (1) improve students' mathematical communication skills through the STAD Type Cooperative Learning Model with the Reciprocal Teaching Approach in MTs Islamiyah Medan, (2) describe the process of implementing the STAD Type Cooperative Learning Model with the Reciprocal Teaching Approach at MTs Islamiyah Medan. This research is a class action research with 31 students of VII-2 MTs Islamiyah Medan subject. Instruments used include learning implementation observation sheets, mathematical communication observation sheets, and mathematical communication test questions. Implementation of the STAD Cooperative Learning Model with the Reciprocal Teaching Approach includes: (1) Initial Activities: the teacher conveys apperception and motivation regarding the material to be studied; (2) this activity: group work which includes Clarifying discussion, Predicting discussion Questioning discussion, Summarizing discussion, discussion of LKS questions, and group percentage; (3) Closing: the teacher together with students draw conclusions on the material that has been learned. After learning takes place there is an increase in students' mathematical communication skills. This can be seen from the results of observations of the implementation of learning an increase in the percentage from cycle I to cycle II amounted to $90.90 \%$ to $94.45 \%$ with a very good category of accuracy. Furthermore, the results of observations of students' mathematical abilities also increased from cycle I by $75.00 \%$ (good category) to $82.41 \%$ (good category) in the second cycle. This is in line with the results of a mathematical communication test that has increased after the second cycle, which is as many as 27 students or $64.52 \%$ of the number of students in class VII-2 has increased in total scores to good categories.
\end{abstract}

Keywords: Mathematical Communication, Cooperative, STAD, Reciprocal Teaching.

\begin{abstract}
Abstrak. Penelitian ini bertujuan untuk (1) meningkatkan kemampuan komunikasi matematis siswa melalui Model Pembelajaran Kooperatif Tipe STAD dengan Pendekatan Reciprocal Teaching di MTs Islamiyah Medan, (2) mendeskripsikan proses pelaksanaan Model Pembelajaran Kooperatif Tipe STAD dengan Pendekatan Reciprocal Teaching di MTs Islamiyah Medan. Penelitian ini merupakan penelitian tindakan kelas dengan subjek siswa kelas VII-2 MTs Islamiyah Medan sebanyak 31 orang. Instrument yang digunakan meliputi: lembar observasi pelaksanaan pembelajaran, lembar observasi komunikasi matematis, dan soal tes komunikasi matematis. Pelaksanaan Model Pembelajaran Kooperatif Tipe STAD dengan Pendekatan Reciprocal Teaching meliputi: (1) Kegiatan Awal: guru menyampaikan apersepsi dan motivasi mengenai materi yang akan dipelajari; (2) kegiatan ini: kerja kelompok yang meliputi diskusi Clarifying, diskusi Predicting diskusi Questioning, diskusi Summarizing, diskusi soal-soal LKS, dan presentase kelompok; (3) Penutup: guru bersama-sama dengan siswa menarik kesimpulan atas materi yang telah dipelajari. Setelah dilaksanakan pembelajaran terjadi peningkatan kemampuan komunikasi matematis siswa. Hal ini dapat dilihat dari hasil observasi keterlaksanaan pembelajaran terjadi peningkatan persentase dari siklus I ke siklus II sebesar 90,90\% menjadi 94,45\% dengan katagori keterlaksaan sangat baik. Selanjutnya, hasil observasi kemampuan matematis siswa juga mengalami peningkatan dari siklus I sebesar $75,00 \%$ (kategori baik) menjadi 82,41\% (kategori baik) pada siklus II. Hal ini sejalan dengan hasil tes komunikasi matematis yang mengalami peningkatan setelah siklus II, yaitu sebanyak 27 siswa atau $64,52 \%$ dari banyaknya siswa kelas VII-2 mengalami peningkatan pada skor total hingga berkategori baik.
\end{abstract}

Kata Kunci: Komunikasi Matematis, Kooperatif, STAD, Reciprocal Teaching. 


\section{PENDAHULUAN}

Salah satu bagian dari pendidikan yang diberikan di sekolah ialah pembelajaran matematika. Perkembangan ilmu pengetahuan dan teknologi tidak luput dari peran matematika didalamnya. Matematika dibutuhkan untuk kebutuhan praktis dan memecahkan masalah dalam kehidupan sehari-hari. Misalnya, dapat berhitung, dapat menghitung isi dan berat, dapat mengumpulkan, mengelola, menyajikan dan menafsirkan data. Matematika juga diperlukan sebagai penyempurna ilmu lainnya. Terkait dengan pentingnya matematika, Concroft (Abdurrahman, 2009) juga mengemukakan alasannya perlu belajar matematika, yaitu:

Matematika perlu diajarkan kepada siswa karena: (1) selalu digunakan dalam segala segi kehidupan, (2) semua bidang studi memerlukan keterampilan matematika yang sesuai, (3) merupakan sarana komunikasi yang kuat, singkat, dan jelas, (4) dapat digunakan untuk menyajikan informasi dalam berbagai cara, (5) meningkatkan kemampuan berpikir logis, ketelitian, dan kesadaran, dan (6) memberikan kepuasan terhadap usaha memecahkan masalah yang menantang.

National Council of Teachers of Mathematics (2000) menyatakan bahwa pembelajaran matematika di sekolah dari jenjang pendidikan dasar hingga kelas XII memerlukan standar pembelajaran yang berfungsi untuk menghasilkan siswa yang memiliki kemampuan berpikir, kemampuan penalaran matematis, memiliki pengerahuan serta keterampilan dasar yang bermanfaat. Standar pembelajaran tersebut meliputi standar isi dan standar proses. Standar isi adalah standar pembelajaran matematika yang memuat konsep-konsep materi yang harus dipelajari oleh siswa, yaitu: bilangan dan operasinya, aljabar, geometri, pengukuran, analisis data dan peluang. Sedangkan standar proses adalah kemampuan-kemampuan yang harus dimiliki siswa untuk mencapai standar isi. Standar proses meliputi pemecahan masalah (problem solving), penalaran (reasoning), komunikasi (communication), penelusuran pola dan hubungan (connections), dan representasi (representation).

Salah satu dari standar proses pembelajaran matematika adalah komunikasi (communication). Komunikasi matematika perlu menjadi fokus perhatian dalam pembelajaran matematika, sebab melalui komunikasi siswa dapat mengorganisasikan dan mengkonsolidasi berpikir matematisnya (NCTM, 2000). Selain itu menurut Atkins (Umar, 2012) komunikasi matematika secara verbal (mathematical conversation) merupakan alat untuk mengukur peningkatan pemahaman siswa, memungkinkan siswa untuk belajar mengkonstruksikan pemahaman matematika dari siswa lain dan memberikan siswa kesempatan untuk merefleksikan pemahaman matematikanya. Kesadaran tentang pentingnya memperhatikan kemampuan siswa dalam berkomunikasi dengan menggunakan matematika yang dipelajari di sekolah perlu ditumbuhkan, sebab salah satu fungsi pembelajaran matematika adalah cara mengkomunikasikan gagasan secara praktis, sistematis, dan efisien.

Tetapi berdasarkan fakta dilapangan dari observasi pembelajaran matematika pada materi sudut dan garis di kelas VII MTs Islamiyah Medan kemampuan komunikasi matematis diperoleh masih rendah. Rendahnya kemampuan komunikasi matematis kelas VII MTs Islamiyah Medan tidak terlepas dari proses pembelajarannya. Pembelajaran matematika masih banyak menggunakan rumus-rumus yang sudah baku dan guru juga jarang menggunakan model pembelajaraan kooperatif salah satunya pembelajaran kooperatif tipe STAD serta guru jarang menggunakan pendekatan saat mengajar. Hal ini menyebabkan proses pembelajaran masih cenderung pasif dan peserta didik kurang kreatif sehingga masih terpusat pada guru (Teacher Centered). Guru aktif menjelaskan sedangkan sebagian besar siswa hanya memperhatikan serta mencatat materi saja. Siswa yang tidak dilibatkan untuk aktif dalam pembelajaran, dapat menyebabkan siswa sulit untuk 
bereksplorasi, berkreatifitas terhadap ide-ide yang mereka miliki khususnya ide-ide matematika. Proses pembelajaran seperti ini menjadikan siswa tidak komunikatif dan tidak mempunyai keterampilan dalam mengembangkan dirinya. Hal ini mengakibatkan kebosanan pada siswa yang berdampak pada kecenderungan untuk melakukan aktivitas lain yang lebih menarik perhatian siswa, seperti mengobrol dengan temannya ataupun menggambar. Oleh karena itu sebagian siswa tidak menyukai pokok pembahasan aljabar, mereka menganggap pokok bahasan sudut dan garis merupakan pokok bahasan yang sulit dipahami dan dimengerti. Hal ini mengakibatkan hasil belajar siswa pokok bahasan sudut dan garis rendah.

Berdasarkan hasil wawancara dari salah satu guru matematika di SMP Tunas Pelita Binjai dapat di simpulkan bahwa siswa yang menganggap mata pelajaran matematika adalah mata pelajaran yang sulit ialah momok mereka yang membuat mereka sulit menerima pelajaran matematika dan membuat mereka ketakutan akan pelajaran matematika, salah satu solusi yang dilakukan guru adalah menekankan aturan atau memberikan gambaran bahwa matematika itu menyenangkan dan memberikan masukan kepada siswa untuk menimbulkan rasa suka terhadap gurunya agar pelajaran yang diajarkan oleh guru mudah diterima.

Atas dasar permasalahan tersebut maka kemampuan komunikasi matematis siswa harus ditingkatkan. Peningkatan kemampuan komunikasi matematis siswa dapat dilakukan dengan mengadakan perubahan-perubahan dalam pembelajaran. Dalam hal ini, perlu dirancang suatu pembelajaran yang membiasakan siswa untuk mengkonstruksi pemikirannya baik dengan guru, teman maupun terhadap materi matematika itu sendiri. Salah satu cara yang dapat dilakukan untuk meningkatkan kemampuan komunikasi matematis siswa adalah dengan menerapkan model pembelajaran yang tepat.

Untuk mengembangkan kemampuan komunikasi matematis siswa, guru dapat menerapkan beberapa pendekatan dengan model tertentu yang sesuai dengan unsur komunikasi matematis, salah satunya adalah model pembelajaran kooperatif tipe STAD dengan pendekatan Reciprocal Teaching. Model pembelajaran kooperatif adalah model pembelajaran yang menekankan kerjasama siswa dalam kelompok kecil yang heterogen serta beranggotakan empat orang untuk menguasai materi pelajaran yang disampaikan oleh guru (Slavin, 2008). Model pembelajaran kooperatif memiliki beberapa tipe. Salah satu tipe model pembelajaran kooperatif yang dapat mendorong partisipasi aktif siswa di dalam kelas adalah model pembelajaran kooperatif tipe Student Teams Achievement Division (STAD) merupakan jenis pembelajaran kooperatif yang dirancang untuk mempengaruhi pola interaksi siswa serta memberikan kesempatan kepada setiap siswa untuk menunjukkan partisipasinya kepada orang lain. Menurut Trianto (2010), pembelajaran kooperatif tipe STAD merupakan salah satu tipe dari model pembelajaran kooperatif dengan menggunakan kelompok-kelompok kecil dengan jumlah anggota tiap kelompok 4 sampai 5 orang secara heterogen. Diawali dengan penyampaian tujuan pembelajaran, penyampaian materi, kegiatan kelompok, kuis, dan penghargaan kelompok.

Kelebihan model pembelajaran kooperatif tipe STAD, yaitu: 1) Dapat memberikan kesempatan kepada siswa untuk menggunakan keterampilan bertanya dan membahas suatu masalah, 2) Dapat memberikan kesempatan kepada siswa untuk lebih intensif mengadakan penyelidikan mengenai suatu masalah, 3) Dapat mengembangkan bakat kepemimpinan dan mengajarkan keterampilan berdiskusi, 4) Dapat memungkinkan guru untuk lebih memperhatikan siswa sebagai individu dan kebutuhan belajarnya, 5) Para siswa lebih aktif bergabung dalam pelajaran mereka dan mereka lebih aktif dalam diskusi, 6) Dapat memberikan kesempatan kepada siswa untuk mengembangkan rasa menghargai, menghormati pribadi temannya, dan menghargai pendapat orang lain. 
Reciprocal Teaching adalah suatu pendekatan yang dirancang untuk mengajarkan kepada siswa tentang pendekatan-pendekatan kognitif sehingga membantu siswa dalam memahami materi pembelajaran dengan baik (Arends, 1997). Pendekatan Reciprocal Teaching dengan model pembelajaran kooperatif merupakan pendekatan yang mengajarkan kepada siswa tentang empat strategi kognitif yang dilakukan siswa secara berkelompok agar siswa dapat memahami suatu materi pelajaran dengan baik. Empat pendekatan kognitif tersebut meliputi: klarifikasi (Clarifying), prediksi (Predicting), membuat pertanyaan (Questioning), dan merangkum (Summarizing). Pada tahap Clarifying, siswa diminta untuk mengklarifikasi/menjelaskan definisi dari istilah-istilah maupun kalimat-kalimat yang belum dipahami dari suatu materi yang telah dibacanya. Tahap predicting, siswa diminta untuk memprediksikan hubungan antara konsep materi satu dengan konsep materi yang lain dalam matematika. Pada tahap Questioning, siswa diminta untuk membuat soal/pertanyaan sendiri yang berkaitan dengan materi yang sedang dipelajari kemudian menjawabnya. Pada tahap terakhir yaitu tahap Summarizing, siswa diminta untuk merangkum materi pembelajaran yang telah dipelajari.

Dalam pendekatan Reciprocal Teaching, siswa berperan sebagai "guru" terhadap teman teman sekelompoknya, sedangkan guru sebenarnya lebih berperan sebagai pembimbing dan fasilitator. Di samping itu, melalui pendekatan Reciprocal Teaching dengan model pembelajaran kooperatif ini, siswa dapat berdialog dan berinteraksi dengan sesama siswa secara terbuka dan interaktif dalam kelompok di bawah bimbingan guru sehingga siswa terpacu untuk menguasai materi pembelajaran yang disajikan. Semua anggota kelompok memiliki tanggung jawab untuk memimpin diskusi dalam dialog selama proses pembelajaran berlangsung (Hashey \& Connors, 2003). Penerapan pendekatan Reciprocal Teaching dengan model pembelajaran kooperatif merupakan upaya yang tepat dalam meningkatkan kemampuan komunikasi matematis siswa karena memuat indikatorindikator kemampuan komunikasi matematis.

\section{METODE}

Jenis penelitian yang digunakan adalah Penelitian Tindakan Kelas (PTK) yang dilakukan secara partisipatif dan kolaboratif. Partisipatif artinya peneliti dibantu oleh rekan peneliti untuk terlibat secara langsung dalam penelitian sebagai pengamat sedangkan kolaboratif artinya peneliti berkolaborasi atau bekerjasama dengan guru matematika kelas VII-2 MTs Islamiyah Medan. Adapun tindakan yang akan dilakukan adalah menerapkan Model Pembelajaran Kooperatif Tipe STAD dengan pendekatan Reciprocal Teaching dalam pembelajaran matematika untuk meningkatkan kemampuan komunikasi matematis siswa kelas VII-2 MTs Islamiyah Medan.

Subjek penelitian ini adalah siswa kelas VII-2 MTs Islamiyah Medan tahun pelajaran 2018/2019. Jumlah siswa kelas VII-2 MTs Islamiyah Medan adalah 30 siswa. Subjek penelitian ditentukan setelah peneliti berkonsultasi dengan guru matematika kelas VII dan kepala MTs Islamiyah Medan. Objek penelitian ini adalah keseluruhan proses dan hasil pembelajaran matematika melalui model pembelajaran kooperatif dengan pendekatan Reciprocal Teaching sebagai upaya meningkatkan kemampuan komunikasi matematis siswa kelas VII SMP Tunas Pelita Binjai.

Desain penelitian yang dipergunakan berbentuk siklus yang mengacu pada model Kemmis dan Mc Taggrat. Siklus ini tidak hanya berlangsung satu kali, tetapi beberapa kali hingga tercapai tujuan yang diharapkan. Rencana penelitian tindakan kelas ini, terdiri dari 2 siklus. Tiap siklus dilaksanakan sesuai dengan perubahan yang ingin dicapai, seperti apa yang telah didesain dalam faktor yang diselidiki. Desain yang dipergunakan dalam penelitian tindakan kelas ini berbentuk spiral atau siklus diambil dari Kemis dan MC. Taggart. 
Arikunto (2006) mengemukakan bahwa penelitian tindakan kelas yaitu sebuah kegiatan penelitian yang dilakukan di kelas, dengan menggabungkan batasan pengertian tiga kata inti, yaitu penelitian, tindakan, dan kelas, sehingga dapat disimpulkan bahwa penelitian tindakan kelas merupakan suatu pencermatan terhadap kegiatan belajar berupa suatu tindakan, yang sengaja dimunculkan dan terjadi dalam sebuah kelas secara bersama. Secara garis besar dalam penelitian tindakan kelas terdapat empat tahapan yang lazim dilalui yaitu, perencanaan (planning), pelaksanaan (acting), pengamatan (observing), dan refleksi (reflecting).

Penelitian ini dilakukan dalam beberapa siklus (siklus I, II dan seterusnya) untuk melihat peningkatan kemampuan komunikasi matematis siswa dalam pembelajaran matematika melalui model pembelajaran kooperatif tipe STAD dengan pendekatan Reciprocal Teaching. Siklus dihentikan jika pembelajaran matematika melalui model pembelajaran kooperatif tipe STAD pendekatan Reciprocal Teaching telah mencapai indikator keberhasilan. Indikator keberhasilan pada penelitian ini ditentukan sebagai berikut:

1. Keterlaksanaan pembelajaran melalui pendekatan Reciprocal Teaching dengan model pembelajaran kooperatif berada dalam kategori Sangat baik.

2. Berdasarkan hasil observasi komunikasi matematis, kemampuan komunikasi matematis siswa kelas VII meningkat dari siklus I ke siklus selanjutnya mencapai kategori baik.

3. Adanya peningkatan kemampuan komunikasi matematika siswa setelah diterapkan pendekatan Recipocal Teaching dengan model pembelajaran Kooperatif Tipe STAD dari siklus I ke siklus II dengan membandingkan antara skor tes pada siklus I dan skor tes pada siklus II dengan kriteria minimal $60 \%$ dari jumlah siswa mengalami peningkatan di atas KKM pada skor total indikator kemampuan komunikasi matematika.

\section{HASIL DAN PEMBAHASAN}

\section{Hasil Observasi Keterlaksanaan Model Pembelajaran Kooperatif Tipe STAD dengan Pendekatan Reciprocal Teaching}

Penelitian tindakan kelas ini dilaksanakan dalam dua siklus dengan lima kali pertemuan, yaitu siklus I dilaksanakan dalam dua kali pertemuan dan siklus II dilaksanakan dalam tiga kali pertemuan. Pada setiap siklus, guru telah berusaha menerapkan Model Pembelajaran Kooperatif tipe STAD dengan Pendekatan Reciprocal Teaching dengan baik. Secara umum, pelaksanaan pembelajaran berlangsung dengan lancar meskipun terdapat keterbatasan waktu. Pada pertemuan 1 siklus I, terdapat beberapa siswa yang masih bingung dan belum memahami sepenuhnya Model Pembelajaran Kooperatif tipe STAD dengan pendekatan Reciprocal Teaching karena pembelajaran ini masih baru bagi mereka. Meski demikian, pada pertemuan berikutnya, siswa mulai terbiasa dengan alur pembelajaran yang digunakan dan bisa melaksanakan setiap tahap pembelajaran dengan lebih tertib dari pada sebelumnya.

Selain mendeskripsikan hasil observasi pelaksanaan pembelajaran, peneliti juga telah menganalisis hasil observasi pelaksanaan pembelajaran tersebut dengan persentase keterlaksanaan pembelajaran. Hasil yang diperoleh sebagai berikut:

1) Siklus I

Keterlaksanaan pembelajaran pada pertemuan 1 dan 2 dalam siklus I mencapai 90,90\% dengan kualifikasi persentase "Sangat Baik".

2) Siklus II

Keterlaksanaan pembelajaran pada pertemuan 1, pertemuan 2 dan pertemuan 3 dalam siklus II mencapai 95.45\% dengan kualifikasi persentase "Sangat Baik".

Persentase hasil observasi pelaksanaan pembelajaran dari siklus I ke siklus II mengalami peningkatan. Kegiatan tersebut meliputi: guru menjelaskan alur model 
pembelajaran kooperatif tipe STAD dengan pendekatan Reciprocal Teaching dan guru memberikan kesempatan bertanya kepada siswa tentang pembelajaran dengan model pembelajaran kooperatif tipe STAD dengan pendekatan Reciprocal Teaching. Persentase keterlaksanaan pembelajaran di atas dihitung berdasarkan pedoman penskoran lembar observasi pelaksanaan pembelajaran yang telah dibuat.

\section{Hasil Observasi Kemampuan Komunikasi Matematis siswa}

Data kemampuan komunikasi matematis siswa berdasarkan hasil observasi kemampuan komunikasi matematis siswa telah disajikan tiap siklus penelitian, sedangkan peningkatan kemampuan komunikasi matematis siswa dari siklus I ke siklus II akan disajikan pada Tabel berikut:

Tabel 1. Peningkatan Kemampuan Komunikasi Matematis Siswa Dari Siklus I ke Siklus II

\begin{tabular}{|c|c|c|c|c|c|}
\hline \multirow[b]{3}{*}{ Kelompok } & \multicolumn{2}{|l|}{ SIKLUS I } & \multicolumn{3}{|c|}{ SIKLUS II } \\
\hline & \multicolumn{2}{|c|}{ Skor rata-rata } & \multicolumn{3}{|c|}{ Skor rata-rata } \\
\hline & $\begin{array}{c}\text { Pertemuan } \\
1\end{array}$ & $\begin{array}{c}\text { Pertemuan } \\
2\end{array}$ & $\begin{array}{c}\text { Pertemuan } \\
1\end{array}$ & $\begin{array}{c}\text { Pertemuan } \\
2\end{array}$ & $\begin{array}{c}\text { Pertemuan } \\
3\end{array}$ \\
\hline 1 & 66,67 & 83,33 & 83,33 & 83,33 & 91,67 \\
\hline 2 & 66,67 & 75,00 & 75,00 & 83,33 & 91,67 \\
\hline 3 & 75,00 & 83,33 & 75,00 & 83,33 & 83,33 \\
\hline 4 & 75,00 & 75,00 & 75,00 & 75,00 & 91,67 \\
\hline 5 & 75,00 & 75,00 & 75,00 & 83,33 & 83,33 \\
\hline 6 & 75,00 & 75,00 & 75,00 & 83,33 & 91,67 \\
\hline Jumlah & 433,34 & 466,66 & 458,33 & 491,65 & 533,34 \\
\hline Rata-rata & 72,22 & 72,78 & 76,39 & 81,94 & 88,89 \\
\hline $\begin{array}{c}\text { Rerata } \\
\text { Total } \\
\end{array}$ & \multicolumn{2}{|c|}{75,00} & \multicolumn{3}{|c|}{82,41} \\
\hline Kategori & \multicolumn{2}{|c|}{ Baik } & \multicolumn{3}{|c|}{ Baik } \\
\hline
\end{tabular}

Apabila tabel di atas digambarkan dalam sebuah diagram maka diperoleh hasil sebagai berikut:

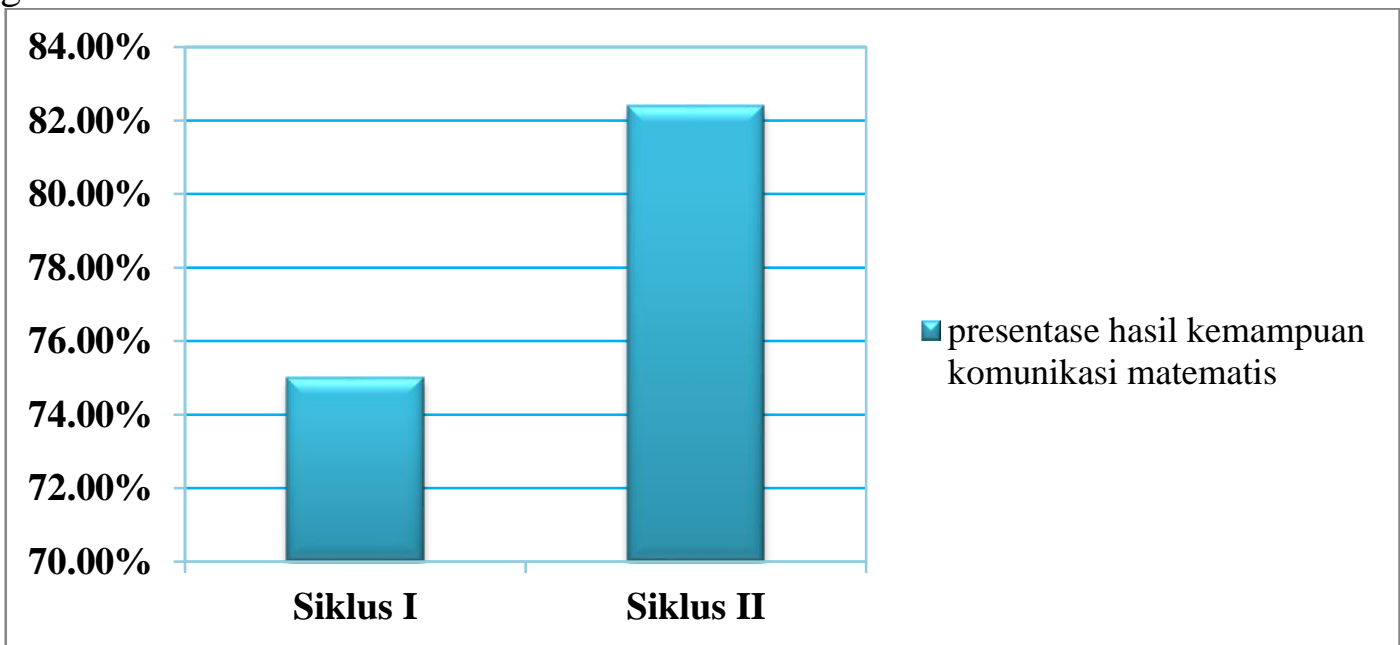

Gambar 1. Diagram Peningkatan Kemampuan Komunikasi Matematis Siswa

Berdasarkan tabel 1, Gambar 1 diatas, dapat disimpulkan bahwa terjadi peningkatan presentase kemampuan komunikasi matematis siswa dari siklus I ke siklus II sebesar $75 \%$ (kategori baik) menjadi 82,41\% (kategori baik). 
Meningkatkan Kemampuan Komunikasi Matematis Siswa Melalui Model...

\section{Hasil Tes Komunikasi Matematis}

Peningkatan skor total kemampuan komunikasi matematis siswa berdasarkan hasil tes komunikasi matematis akan disajikan pada Tabel berikut:

Tabel 2. Peningkatan Kemampuan Komunikasi Matematis Siswa pada Siklus I dan II

\begin{tabular}{|c|c|c|c|c|c|c|c|c|c|c|c|c|c|c|}
\hline \multirow{3}{*}{ No } & \multicolumn{6}{|c|}{ Siklus I } & \multicolumn{6}{|c|}{$\begin{array}{l}\text { Siklus II } \\
\end{array}$} & \multirow{3}{*}{$\begin{array}{l}\text { Keterangan } \\
\text { Peningkatan }\end{array}$} & \multirow{3}{*}{$\begin{array}{l}\text { Meningkat Hingga } \\
\text { Kategori Baik }\end{array}$} \\
\hline & \multirow{2}{*}{$\begin{array}{l}\text { Kode } \\
\text { Siswa }\end{array}$} & \multicolumn{4}{|c|}{ Butir Soal } & \multirow{2}{*}{ Nilai } & \multicolumn{5}{|c|}{ Butir Soal } & \multirow{2}{*}{ Nilai } & & \\
\hline & & 1 & 2 & 3 & 4 & & 1 & 2 & 3 & 4 & 5 & & & \\
\hline 1 & S.1 & 4 & 6 & 3 & 7 & 60 & 3 & 7 & 6 & 8 & 4 & 31 & Tidak & tidak \\
\hline 2 & S.2 & 1 & 5 & 5 & 7 & 55 & 3 & 7 & 6 & 8 & 4 & 40 & Meningkat & tidak \\
\hline 3 & S.3 & 1 & 6 & 5 & 7 & 58 & 3 & 7 & 6 & 10 & 3 & 40 & Tidak & tidak \\
\hline 4 & S.4 & 7 & 6 & 7 & 7 & 82 & 3 & 7 & 5 & 10 & 4 & 71 & Meningkat & meningkat \\
\hline 5 & S.5 & 3 & 6 & 3 & 7 & 58 & 7 & 7 & 6 & 10 & 4 & 66 & Meningkat & Meningkat \\
\hline 6 & S.6 & 4 & 3 & 7 & 7 & 64 & 7 & 7 & 6 & 10 & 4 & 69 & Meningkat & Meningkat \\
\hline 7 & S.7 & 0 & 6 & 6 & 3 & 45 & 7 & 7 & 6 & 4 & 4 & 71 & Meningkat & Meningkat \\
\hline 8 & S.8 & 0 & 0 & 4 & 4 & 24 & 7 & 7 & 6 & 6 & 4 & 31 & Meningkat & Tidak \\
\hline 9 & S.9 & 0 & 6 & 3 & 5 & 42 & 7 & 7 & 6 & 8 & 4 & 46 & Meningkat & Tidak \\
\hline 10 & S.10 & 6 & 6 & 3 & 7 & 67 & 7 & 4 & 5 & 6 & 0 & 40 & Tidak & Tidak \\
\hline 11 & S.11 & 0 & 0 & 7 & 6 & 39 & 0 & 4 & 5 & 8 & 4 & 69 & Meningkat & Meningkat \\
\hline 12 & S.12 & 1 & 5 & 0 & 0 & 18 & 0 & 4 & 5 & 5 & 0 & 49 & Meningkat & $\begin{array}{l}\text { Tidak } \\
\end{array}$ \\
\hline 13 & S.13 & 0 & 6 & 3 & 0 & 27 & 7 & 4 & 5 & 6 & 4 & 63 & Meningkat & Meningkat \\
\hline 14 & S.14 & 7 & 3 & 7 & 7 & 73 & 6 & 4 & 5 & 5 & 4 & 49 & Tidak & Tidak \\
\hline 15 & S.15 & 0 & 6 & 3 & 3 & 36 & 7 & 4 & 5 & 6 & 4 & 71 & Meningkat & Meningkat \\
\hline 16 & S.16 & 7 & 3 & 3 & 7 & 61 & 0 & 7 & 2 & 8 & 4 & 66 & Meningkat & Meningkat \\
\hline 17 & S.17 & 3 & 6 & 7 & 4 & 61 & 7 & 4 & 2 & 4 & 4 & 69 & Meningkat & Meningkat \\
\hline 18 & S.18 & 0 & 6 & 7 & 7 & 61 & 7 & 5 & 2 & 8 & 4 & 69 & Meningkat & Meningkat \\
\hline 19 & S.19 & 7 & 6 & 3 & 3 & 58 & 7 & 7 & 2 & 4 & 0 & 63 & Meningkat & Meningkat \\
\hline 20 & S.20 & 0 & 6 & 7 & 7 & 61 & 6 & 4 & 2 & 4 & 4 & 69 & Meningkat & Meningkat \\
\hline 21 & S.21 & 7 & 4 & 7 & 7 & 76 & 0 & 6 & 6 & 8 & 4 & 66 & Meningkat & Meningkat \\
\hline 22 & S.22 & 1 & 6 & 3 & 3 & 39 & 6 & 4 & 2 & 10 & 4 & 54 & Meningkat & Tidak \\
\hline 23 & S.23 & 1 & 3 & 3 & 3 & 30 & 3 & 4 & 2 & 8 & 4 & 94 & Meningkat & Meningkat \\
\hline 24 & S.24 & 0 & 3 & 3 & 5 & 33 & 4 & 7 & 2 & 10 & 4 & 86 & Meningkat & Meningkat \\
\hline 25 & S.25 & 1 & 4 & 7 & 0 & 36 & 4 & 4 & 0 & 8 & 4 & 54 & Meningkat & $\begin{array}{l}\text { Tidak } \\
\end{array}$ \\
\hline 26 & S.26 & 0 & 4 & 3 & 5 & 36 & 4 & 7 & 0 & 10 & 4 & 51 & Meningkat & Tidak \\
\hline 27 & S.27 & 0 & 3 & 3 & 7 & 39 & 4 & 7 & 0 & 10 & 4 & 60 & Meningkat & Meningkat \\
\hline 28 & S.28 & 0 & 0 & 6 & 5 & 33 & 4 & 4 & 2 & 8 & 4 & 74 & Meningkat & Meningkat \\
\hline 29 & S.29 & 1 & 3 & 3 & 5 & 36 & 4 & 7 & 5 & 5 & 4 & 71 & Meningkat & Meningkat \\
\hline 30 & S.30 & 1 & 0 & 3 & 7 & 33 & 5 & 7 & 2 & 10 & 4 & 80 & Meningkat & Meningkat \\
\hline 31 & S.31 & 1 & 0 & 6 & 9 & 48 & 4 & 7 & 6 & 10 & 4 & 97 & Meningkat & Meningkat \\
\hline & otal & 64 & 127 & 140 & 161 & 1489 & 143 & 178 & 120 & 235 & 111 & 1929 & & \\
\hline & a-rata & 2.06 & 4.1 & 4.52 & 5.2 & 48.03 & 4.61 & 5.74 & 3.9 & 7.58 & 3.6 & 62.23 & & \\
\hline
\end{tabular}

Banyak siswa yang mengalami peningkatan Skor total kemampuan komunikasi matematis dari siklus I ke siklus II

27 Siswa

20 Siswa

Banyak siswa yang mengalami peningkatan Skor total kemampuan komunikasi matematis dari siklus I ke siklus II hingga kategori baik

Presentase siswa yang mengalami peningkatan pada skor total kemampuan komunikasi matematis hingga kategori baik

$64,52 \%$

Berdasarkan tabel di atas, diperoleh bahwa sebanyak 27 siswa kelas VII mengalami peningkatan skor total kemampuan komunikasi matematis dari siklus I ke siklus II. Dari 27 siswa, terdapat 1 siswa yang mengalami peningkatan skor total hingga kategori kurang baik, 6 siswa mengalami peningkatan skor total hingga kategori cukup baik, dan 20 siswa atau $64,52 \%$ dari banyaknya siswa kelas VII mengalami peningkatan skor total kemampuan komunikasi matematis hingga berkategori baik. 


\section{Pembahasan}

Penelitian ini merupakan penelitian tindakan kelas untuk mengatasi permasalahan kurangnya kemampuan komunikasi matematis siswa. Oleh karena itu, selama pelaksanaan tindakan kelas, guru berusaha menerapkan model pembelajaran kooperatif tipe STAD dengan pendekatan Reciprocal Teaching dengan baik meskipun mengalami beberapa kendala pada pelaksanaan siklus I, yaitu terdapat beberapa siswa yang masih membuka buku paket matematika pada saat pelaksanaan diskusi kelompok, beberapa siswa masih pasif dalam diskusi tertentu, dan kurangnya kontrol untuk pengalokasian waktu pelaksanaan tahap-tahap diskusi Reciprocal Teaching sehingga menyita banyak waktu pembelajaran. Tiga hal pokok tersebut terjadi karena model pembelajaran kooperatif tipe STAD dengan Reciprocal Teaching baru pertama kali dilaksanakan dalam kelas VII sehingga siswa masih berusaha untuk menyesuaikan diri dengan pembelajaran tersebut.

Pelaksanaan model pembelajaran kooperatif tipe STAD dengan pendekatan Reciprocal Teaching pada siklus II bukan lagi menjadi masalah karena siswa telah menyesuaikan diri terhadap pembelajaran tersebut dan siswa menjadi lebih aktif dalam kelompoknya sehingga pelaksanaan setiap kegiatan pembelajaran berlangsung lebih tertib daripada sebelumnya.

Pelaksanaan tindakan model pembelajaran kooperatif tipe STAD dengan pendekatan Reciprocal Teaching memuat dua tahapan penting, yaitu: tahap kerja kelompok dan tahap presentasi kelompok. Tahap pelaksanaan kerja kelompok siklus I berjalan cukup baik meskipun terdapat beberapa kendala seperti: kurangnya pemahaman siswa dalam menyelesaikan LKS Predicting serta kurang aktifnya siswa dalam berdiskusi jika menemui soal yang tingkat kesulitannya lebih tinggi. Beberapa siswa yang cenderung pasif pada siklus I, berangsur-angsur menjadi aktif berdiskusi pada siklus II. Berdasarkan hasil pengamatan observer, dapat diketahui bahwa kesulitan siswa dalam memahami suatu materi menyebabkan siswa bersifat pasif dalam diskusi kelompok. Namun, kesulitankesulitan yang dihadapi siswa dalam memahami materi tersebut dapat diminimalisir dengan penjelasan yang dilakukan oleh guru. Pada tahap presentasi kelompok, untuk pertemuan 1 siklus I, siswa kelas VII belum menunjukkan keberaniannya dalam mempresentasikan hasil diskusinya di depan kelas, sehingga guru harus menunjuk salah satu perwakilan kelompok untuk presentasi ke depan kelas. Namun, pada pertemuan berikutnya, siswa mulai berani untuk presentasi sehingga guru tidak perlu menunjuk perwakilan kelompok.Untuk kemampuan komunikasi matematis siswa, berdasarkan hasil observasi komunikasi matematis, terjadi peningkatan kemampuan komunikasi matematis seluruh siswa hingga mencapai kategori baik dari siklus I ke siklus II yang mencakup Menghubungkan benda nyata, gambar, dan diagram ke dalam ide matematika, Menjelaskan ide, situasi dan relasi matematik secara tulisan, dan Menyatakan peristiwa atau ide dalam bahasa atau simbol matematika dari siklus I ke siklus II. Peningkatan tersebut merupakan dampak dari penerapan model pembelajaran kooperatif tipe STAD dengan pendekatan Reciprocal Teaching. Pembelajaran matematika yang dilaksanakan model pembelajaran kooperatif tipe STAD dengan pendekatan Reciprocal Teaching yang mampu meningkatkan kemampuan komunikasi matematis siswa secara umum berjalan dengan baik dan dilaksanakan sesuai dengan tahapan dalam model pembelajaran kooperatif tipe STAD dengan pendekatan Reciprocal Teaching.

Pada awal pembelajaran, guru mengkomunikasikan tujuan yang akan dicapai dalam pembelajaran, kemudian guru memberikan apersepsi dengan melakukan tanya jawab dengan siswa. Guru mengingatkan siswa pada materi sebelumnya dan menghubungkan antara pengetahuan yang telah dimiliki siswa sebelumnya dengan materi yang akan dipelajari. Hal ini bertujuan agar siswa termotivasi dalam belajar karena telah memiliki gambaran terhadap materi yang akan dipelajari pada hari ini. Menurut Depdiknas (2004), 
pemberian apersepsi sebagai upaya yang dilakukan guru untuk memotivasi siswa agar berperan penuh selama proses kegiatan pembelajaran dan untuk membangkitkan perhatian siswa terhadap materi yang dipelajari.

Setelah memberikan apersepsi, guru memberikan persoalan berupa LKS Reciprocal Teaching yang memuat 4 macam tahapan dalam Reciprocal Teaching, yaitu : LKS Clarifying, LKS Predicting, LKS Questioning, dan LKS Summarizing kepada setiap siswa dan siswa diminta untuk menyelesaikan soal pada LKS secara berkelompok. Dengan adanya kerjasama siswa dalam suatu kelompok, diharapkan mampu membantu proses klarifikasi siswa pada saat belajar. Di samping itu, dengan adanya kelompok belajar siswa, diharapkan agar setiap anggota kelompok dapat berkomunikasi dengan nyaman dalam menyampaikan pendapat ataupun bertanya untuk bertukar pemahaman materi sehingga mendukung proses konstruksi pengetahuan siswa dalam pembelajaran Reciprocal Teaching (Palincsar \& Brown, 1984:118).

Tahap diskusi pertama dalam pendekatan Reciprocal Teaching adalah diskusi Clarifying. Diskusi Clarifying memuat indikator kemampuan komunikasi matematis Menjelaskan ide, situasi dan relasi matematik secara tulisan karena pada tahap diskusi ini, siswa dilatih untuk mampu mengklarifikasi atau menjelaskan kembali definisi dari istilah matematika yang terdapat dalam LKS clarifying dengan berdiskusi secara berkelompok dengan pimpinan siswa yang disebut sebagai clarifier.

Tahap diskusi kedua adalah diskusi Predicting. Diskusi Predicting memuat indikator kemampuan komunikasi matematis Menjelaskan ide, situasi dan relasi matematik secara tulisan karena pada tahap diskusi ini, siswa dilatih untuk membuat dugaan/membuat prediksi tentang hubungan antar konsep yang terdapat dalam LKS Predicting dengan pimpinan siswa yang disebut sebagai Predictor. Dalam memprediksikan hubungan antar konsep tersebut, kemampuan siswa dalam memberikan alasan yang rasional terhadap suatu pernyataan/pendapat serta menyatakan ide/gagasan dari suatu soal juga terasah karena soalsoal yang diberikan dalam LKS Predicting merupakan soal kombinasi antara 3 indikator, yaitu membuat dugaan/membuat prediksi tentang hubungan antar konsep, memberikan alasan yang rasional terhadap suatu pernyataan/pendapat, dan menyatakan ide/gagasan dari suatu soal.

Tahap diskusi ketiga adalah diskusi questioning. Diskusi questioning memuat indikator kemampuan komunikasi matematis Menyatakan peristiwa atau ide dalam bahasa atau simbol matematika karena diskusi ini melatih siswa untuk mampu membuat soal atas materi yang sedang dipelajari sekaligus menyelesaikannya secara runtut dengan pimpinan siswa yang disebut Questioner.

Tahap diskusi keempat adalah diskusi summarizing dan diskusi soal-soal latihan. Meskipun diskusi soal-soal latihan tidak merupakan tahap diskusi Reciprocal Teaching tetapi diskusi soal-soal latihan memuat seluruh indikator kemampuan komunikasi matematis, yaitu Menghubungkan benda nyata, gambar, dan diagram ke dalam ide matematika, Menjelaskan ide, situasi dan relasi matematik secara tulisan, dan Menyatakan peristiwa atau ide dalam bahasa atau simbol matematika. Ketiga indikator kemampuan komunikasi matematis yang terangkum dalam soal-soal latihan tersebut melatih siswa untuk menggunakan simbol/notasi, operasi matematika secara tepat guna; menyatakan ide/gagasan dari suatu soal; menjelaskan gambar, grafik, tabel atau kalimat matematika ke dalam uraian yang kontekstual dan sesuai; menyajikan permasalahan kontekstual ke dalam bentuk gambar, grafik, tabel atau aljabar; serta menyampaikan ide, situasi, atau relasi matematika dengan gambar, grafik, tabel, aljabar, atau kalimat secara jelas. Setelah siswa melaksanakan diskusi, siswa memiliki kesempatan untuk mempresentasikan atau menyajikan hasil diskusi kelompok di hadapan seluruh teman sekelas. Presentasi memberikan kesempatan kepada siswa untuk mengungkapkan pendapat siswa sehingga 
siswa merasa dihargai dan akhirnya merasa senang mengikuti pembelajaran (Suherman, 2001).

Pada akhir pembelajaran, guru memberikan kesempatan kepada siswa untuk bertanya mengenai materi yang belum dipahami. Beberapa siswa belum menunjukkan keberanian untuk bertanya sehingga guru harus mengevaluasi kembali materi-materi pokok yang dipresentasikan oleh kelompok penyaji. Evaluasi presentasi kelompok yang dilakukan oleh guru, mampu membawa pemikiran siswa dalam menyimpulkan materi yang telah dipelajari pada pertemuan tersebut.

Selama pembelajaran berlangsung, kegiatan komunikasi matematis siswa diamati dengan menggunakan lembar observasi kemampuan komunikasi matematis siswa. Berdasarkan hasil observasi kemampuan komunikasi matematis siswa selama siklus I dan siklus II diperoleh bahwa kemampuan komunikasi matematis siswa meningkat setelah diterapkan pembelajaran melalui model pembelajaran kooperatif tipe STAD dengan pendekatan Reciprocal Teaching. Peningkatan kemampuan siswa dalam merumuskan suatu definisi dari istilah matematika baik secara lisan maupun tertulis dapat diamati dari peningkatan keaktifan siswa dalam diskusi clarifying serta ketepatan hasil pekerjaan siswa dalam menyelesaikan LKS clarifying.

Peningkatan kemampuan strategis siswa dalam membuat soal/pertanyaan atas materi yang sedang dipelajari sekaligus menyelesaikannya secara runtut juga terlihat dari meningkatnya jumlah siswa yang aktif pada diskusi questioning dari siklus I ke siklus II. Pertanyaan-pertanyaan yang dibuat siswa pada siklus II lebih beragam daripada pertanyaan-pertanyaan pada siklus I. Pada siklus I, pertanyaan-pertanyaan yang dibuat siswa dalam satu kelompok masih bersifat seragam. Sedangkan pada siklus II, pertanyaan yang dibuat oleh mayoritas siswa lebih beragam dan berupa soal cerita yang bersifat kontekstual.

Dapat disimpulkan bahwa terjadi peningkatan skor kemampuan siswa dalam membuat pertanyaan sekaligus menyelesaikannya dari siklus I ke siklus II yang dilihat dari peningkatan jumlah keaktifan siswa dalam berdiskusi questioning serta keberagaman dan ketepatan siswa dalam menyelesaikan soal/pertanyaan yang telah dibuatnya sendiri.

Selain hasil observasi kemampuan komunikasi matematis, pada setiap akhir siklus diadakan tes kemampuan komunikasi matematis. Berdasarkan hasil analisis tes komunikasi matematis tiap siklus pada lampiran, diperoleh informasi bahwa dari 31 siswa kelas VII, terdapat 27 siswa yang mengalami peningkatan pada skor total kemampuan komunikasi matematis dari siklus I ke siklus II. Dari 27 siswa yang mengalami peningkatan skor total kemampuan komunikasi matematis tersebut, terdapat 20 siswa yang mengalami peningkatan skor total kemampuan komunikasi matematis hingga kategori baik, 6 siswa meningkat hingga kategori cukup baik, dan 1 siswa meningkat hingga kategori kurang baik. Jadi terdapat 27 siswa dari 31 siswa kelas VII telah memenuhi indikator keberhasilan penelitian karena banyaknya siswa yang mengalami peningkatan skor total kemampuan komunikasi matematis hingga minimal berkategori baik dari siklus I ke siklus II telah melebihi batas minimal yang telah ditetapkan yaitu $60 \%$.

\section{KESIMPULAN}

Berdasarkan hasil observasi pelaksanaan pembelajaran kooperatif tipe STAD dengan pendekatan reciprocal teaching terjadi peningkatan persentase keterlaksanaan pembelajaran dari $90,90 \%$ pada siklus I menjadi $95,45 \%$ pada siklus II dengan kategori keterlaksaan pembelajaran sangat baik. Sedangkan berdasarkan hasil observasi komunikasi matematis siswa terjadi peningkatan kemampuan komunikasi matematis siswa dari siklus I sebesar 75,00\% (kategori baik) menjadi 82,41\% (kategori baik) pada siklus II. Di samping itu, hasil tes komunikasi matematis tiap siklus juga menunjukkan bahwa 64,52\% dari 
banyaknya siswa kelas VII-2 mengalami peningkatan skor total hingga minimal berkategori baik dari siklus I ke siklus II. Seluruh indikator keberhasilan penelitian telah terpenuhi pada siklus II sehingga pelaksanaan tindakan dihentikan hingga siklus II. Berdasarkan kesimpulan diatas, peneliti merekomendasikan saran sebagai berikut:

1. Pendekatan Reciprocal Teaching perlu dikembangkan lebih lanjut dalam penelitianpenelitian berikutnya untuk meningkatkan indikator kemampuan komunikasi matematis lain sehingga memberikan manfaat yang lebih besar terhadap guru dan siswa dalam pembelajaran matematika.

2. Peneliti lain yang ingin melakukan penelitian melalui pendekatan Reciprocal Teaching agar dapat lebih memperhatikan alokasi waktu yang digunakan untuk setiap tahap strategi diskusi Reciprocal Teaching agar pelaksanaan pembelajaran dengan pendekatan Reciprocal Teaching dapat berjalan lebih baik.

3. Pada tahap diskusi Reciprocal Teaching, guru dan peneliti benar-benar memperhatikan kinerja setiap pemimpin tahap diskusi Clarifying, Predicting, Questioning, maupun Summarizing.

4. Guru maupun calon peneliti diharapkan lebih kreatif dalam menyusun media pembelajaran yang mendukung peningkatan kemampuan komunikasi matematis siswa.

5. Siswa perlu mendapat bimbingan dari berbagai pihak untuk meningkatkan kesadaran akan pentingnya kemampuan komunikasi matematis.

\section{DAFTAR PUSTAKA}

Abdurrahman, M. 2009. Pendidikan Bagi Anak Berkesulitan Belajar. Jakarta Rineka Cipta. Arend, R. 1997. Classroom Instruction and Management. New York: Mc Glaw-Hill Companies.

Arikunto, S. 2006. Dasar-Dasar Evaluasi Pendidikan. Jakarta: Bumi Aksara

Depdiknas. 2004. Materi Pelatihan Terintegrasi Buku 3 Matematika. Jakarta: Departemen Pendidikan Nasional.

Suherman, E., dkk. 2001. Strategi Pembelajaran Matemtika Kontemporer. Bandung: JICA Universitas Pendidikan Indonesia (UPI).

Hasley, J. M \& Connors, D. J. 2003. Learn From Our Journey: Reciprocal Teaching Action Research. Reading Teacher, 57(3)

NCTM. 2000. Principle and Standards for School Mathematics. Reston VA: NCTM.84.

Palincsar, A. \& Brown, A. 1984. Reciprocal Teaching of Comprehention-Fostering and Comprehension-Monitoring Activities. Cognition and Instruction. Vol 1 No 2.

Slavin, R. E. 2008. Cooperative Learning. Bandung: Nusa Media

Trianto. 2010, Mendesain Model Pembelajaran Inovatif-Progresif. Jakarta: Penerbit Kencana Prenada Media Group. 